\title{
Community structure of mayflies (Insecta: Ephemeroptera) in tropical streams of Western Ghats of Southern India
}

\author{
Sivaruban BARATHY1 ${ }^{1}$, Thambiratnam SIVARUBAN ${ }^{2}$ (D) , Muthukumarasamy ARUNACHALAM ${ }^{3}$ D, \\ Pandiarajan SRINIVASAN2 ${ }^{2}$
}

Cite this article as:

Barathy, S., Sivaruban, T., Arunachalam, M., Srinivasan, P. (2021). Community structure of mayflies (Insecta: Ephemeroptera) in tropical streams of Western Ghats of Southern India. Aquatic Research, 4(1), 21-37. https://doi.org/10.3153/AR21003

${ }^{1}$ Fatima College, Department of Zoology, Madurai, 625018, India.

${ }^{2}$ The American College, PG\& Research department of Zoology, Madurai, 625002, India

Central University of Kerala, School of Biological Sciences, Department of Animal Science/Zoology Periyae-671 236, Kasargod, Kerala India

ORCID IDs of the author(s):

S.B. 0000-0002-9464-6464

T.S. 0000-0001-8997-9355

M.A. 0000-0003-3979-2829

P.S. 0000-0001-8118-3256

Submitted: 05.06 .2020

Revision requested: 16.07 .2020

Last revision received: 27.07 .2020

Accepted: 30.07 .2020

Published online: 12.11 .2020

Correspondence:

Sivaruban BARATHY

E-mail: barathyruban@gmail.com

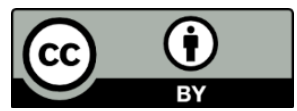

(C) 2021 The Author(s)

Available online at

http://aquatres.scientificwebjournals.com

\begin{abstract}
The main objective of this study was to evaluate the community structure of the order Ephemeroptera in the Southern Western Ghats ecoregion along with Principal Component Analysis (PCA) and Canonical Correspondence Analysis (CCA) from 2017 to 2018. Ecological parameters estimated at each collecting site were $\mathrm{pH}$, dissolved oxygen, biological oxygen demand, hardness and alkalinity. This research investigation was carried out in 30 streams of Palni and Cardamom hills in Western Ghats of Southern India. With PCA examination, the sites like Dhobikana, Fern hill and Poomparai of Palni hills are plotted far apart and are not supported by the ecological parameters like in the other sites. Dhobikana of Palni hills is exceptionally contaminated in light of the fact that dhobis are associated with washing garments so cleanser contamination is prevalent around there. In cardamom hills, Santhamparai near bridge and Nayamakkadu are left far apart indicating they are not supported by physico-chemical parameters, mainly due to pollution. From to the CCA results, it is discovered that Baetis species favor $\beta$-mesosaprobic habitat and Indialis badia inclines toward high altitudinal region. From the outcomes, it is presumed that $\mathrm{pH}$, dissolved oxygen, biological oxygen demand, hardness and alkalinity were the essential components administering the mayfly community and structure.
\end{abstract}

Keywords: PCA, Dhobikana, Dissolved oxygen, pH, Baetis, Ephemera nadinae 


\section{Introduction}

Ephemeroptera also called as mayflies and they are cosmopolitan in distribution (Barber-James et al., 2008). They do secondary production activity in freshwater habitat. Most families of mayflies are sensitive to pollution and they inhabit only in freshwater environment, so they serve as bio indicators of water quality.

Streams and rivers are an example of an important habitat and source of water for all living organism and human being. Pollution either by anthropogenic activity or by nature can unfavorably influence any biological ecosystem. The pollution in the freshwater ecosystem affects the mayfly's richness and diversity. Streams become contaminated by water entering from the farming area or modern destinations, and the nature of the water will be reflected by the kinds of the animals that can endure such as mayflies.

The ecological attributes like $\mathrm{pH}$, turbidity, dissolved oxygen, air temperature, water temperature, alkalinity, total dissolved solids and various pollutants legitimately and by implication influence the mayfly populations. Deforestation is one of the primary threats to mayfly biodiversity and conservation in the tropics (Benstead and Pringle, 2004) whereas pollution (Rosenberg and Resh, 1993) or habitat fragmentation (Zwick, 1992) are the major causes in the temperate areas.

Numerous investigations have been made in recent years on the effect of climate change on mayflies. Clearly, climate changes are affecting the behavior and ultimately the ecology of some mayflies, for example, small increases in temperature $\left(3^{\circ} \mathrm{C}\right)$ over the short term cause early emergence of mayflies (McKee and Atkinson, 2000). Climate changes alter precipitation pattern, leading to greater flood magnitude and frequency in certain rivers. This results in changes in ecological structure and function, and loss of diversity through too frequent scouring. With the continuing trend of temperature increase, the proportion of glacial melt and snow melt waters will change and lead to drastic changes in macroinvertebrate communities, including mayflies.

Ephemeroptera have been extensively used as bioindicators in aquatic biomonitoring programs (Srinivasan et al., 2019), in biomarker studies and in ecotoxicological studies. During the last two decades, EPT concept has successfully emphasized the significance of Ephemeroptera, Plecoptera, and Trichoptera in describing environmental conditions (Lenat and Barbour, 1994). In the current investigation, we utilize multivariate examination strategy Canonical Correspondence
Analysis (CCA) to establish the community structure of mayflies and Principal Component Analysis (PCA) to find the relationship between stations and environmental parameters. Multivariate investigation strategies have just been utilized to consider the connection between benthic macroinvertebrate community and ecological factors in all around the globe from the previous studies (Kazanci et al., 2017; Duran and Akyildiz, 2011). As Palni and Cardamom hills belongs to the southern part of the Western Ghats, which is one of the eight hottest hotspots in the globe (Myers et al., 2000) and no work had to be done in the population dynamics and community structure of mayflies in this part of Western Ghats, so this work aims to assess the relationship between mayfly community and environmental factors in Palni and Cardamom hills of Western Ghats.

\section{Material and Methods}

\section{Study Area}

Mayfly nymphs were collected from 2017- 2018 in thirty sites (16 from Palni hills and 14 from Cardamom hills) using $1 \mathrm{~m}$ wide Kick-net (Burton and Sivaramakrishnan, 1993) with mesh size of about $1 \mathrm{~mm}$ and they were identified with the help of various taxonomical literatures. Table 1 shows the descriptions of these sites. List of mayfly taxa of Palni and Cardamom hills is given in the Table 2 and 3 respectively.

\section{Measuring Physicochemical Parameters}

Water samples were collected from sampling sites and various physicochemical parameters like $\mathrm{pH}$, dissolved oxygen, air temperature, water temperature, water current, width of the stream, hardness, alkalinity, total dissolved solids, conductivity and Biological oxygen demand were analyzed using APHA guidelines (2005).

\section{Statistical Analysis}

To view the trend of distribution of the stations based on environmental parameters the PCA (Principal Components Analysis) was used. PCA was calculated by using PAST software 4.02 (Hammer et al., 2001). Mathematically, PCA consists of Eigen-analysis of a covariance or correlation matrix calculated on the original measurement data. To investigate the relationships between ecological factors and various stations, PCA was used. Canonical Correspondence Analysis (CCA) was made to found the community structure of mayflies in relationship to environmental variables. 
Table 1. Details of the 30 study sites

\begin{tabular}{|c|c|c|c|c|c|c|c|}
\hline $\begin{array}{l}\text { S. } \\
\text { No }\end{array}$ & $\begin{array}{c}\text { Name of } \\
\text { the study site }\end{array}$ & $\begin{array}{l}\text { Abbreviation } \\
\text { in PCA }\end{array}$ & $\begin{array}{l}\text { Abbreviation } \\
\text { in CCA }\end{array}$ & $\begin{array}{c}\text { Stream } \\
\text { order }\end{array}$ & $\begin{array}{l}\text { Altitude } \\
\text { (m) }\end{array}$ & $\begin{array}{c}\text { Latitude } \\
\left(\mathbf{N}^{\circ}\right)\end{array}$ & $\begin{array}{c}\text { Longitude } \\
\left(\mathbf{E}^{\circ}\right)\end{array}$ \\
\hline 1 & Oothu & Ooth & P-1 & 3 & 1300 & $10^{\circ} 12^{\prime}$ & $77^{\circ} 26^{\prime}$ \\
\hline 2 & Perumalmalai & Peru & $\mathrm{P}-2$ & 2 & 1400 & $10^{\circ} 18^{\prime}$ & $77^{\circ} 33^{\prime}$ \\
\hline 3 & Kurusadai & Kuru & P-3 & 2 & 1700 & $10^{\circ} 20^{\prime}$ & $77^{\circ} 28^{\prime}$ \\
\hline 4 & Ghandhi nagar & Gand & P-4 & 2 & 1600 & $10^{\circ} 18^{\prime}$ & $77^{\circ} 27^{\prime}$ \\
\hline 5 & Silver cascade & Silv & P-5 & 2 & 1700 & $10^{\circ} 12^{\prime}$ & $77^{\circ} 28^{\prime}$ \\
\hline 6 & Vattakanal & Vatt & P-6 & 2 & 1000 & $10^{\circ} 11^{\prime}$ & $77^{\circ} 25^{\prime}$ \\
\hline 7 & Fairy falls & Fair & $\mathrm{P}-7$ & 3 & 290 & $10^{\circ} 13^{\prime}$ & $77^{\circ} 27^{\prime}$ \\
\hline 8 & Bear Shola falls & Bear & P-8 & 2 & 300 & $10^{\circ} 14^{\prime}$ & $77^{\circ} 27^{\prime}$ \\
\hline 9 & Fern hill falls & Fern & P-9 & 3 & 122 & $10^{\circ} 12^{\prime}$ & $77^{\circ} 20^{\prime}$ \\
\hline 10 & Pillar rock & Pill & P-10 & 1 & 2250 & $10^{\circ} 17^{\prime}$ & $77^{\circ} 28^{\prime}$ \\
\hline 11 & Near pillar rock & Near pill & P-11 & 1 & 2255 & $10^{\circ} 12^{\prime}$ & $77^{\circ} 30^{\prime}$ \\
\hline 12 & Pambar stream & Pamb & P-12 & 2 & 2248 & $10^{\circ} 13^{\prime}$ & $77^{\circ} 28^{\prime}$ \\
\hline 13 & Dhobikana & Dhob & P-13 & 3 & 2075 & $10^{\circ} 24^{\prime}$ & $77^{\circ} 24^{\prime}$ \\
\hline 14 & GundarFalls & Gund & P-14 & 2 & 2200 & $10^{\circ} 14^{\prime}$ & $77^{\circ} 26^{\prime}$ \\
\hline 15 & Poomparai & Poom & P-15 & 2 & 2133 & $10^{\circ} 13^{\prime}$ & $78^{\circ} 16^{\prime}$ \\
\hline 16 & Kounchi & Kouc & P-16 & 2 & 2360 & $10^{\circ} 29^{\prime}$ & $77^{\circ} 30^{\prime}$ \\
\hline 17 & Kurangani up & Kura-up & $\mathrm{C}-1$ & 2 & 2410 & $11^{\circ} 00^{\prime}$ & $77^{\circ} 50^{\prime}$ \\
\hline 18 & Kurangani down & Kura-down & $\mathrm{C}-2$ & 2 & 2345 & $11^{\circ} 00^{\prime}$ & $77^{\circ} 45^{\prime}$ \\
\hline 19 & B. L. Rave & B.L.Rave & $\mathrm{C}-3$ & 1 & 1250 & $10^{\circ} 11^{\prime}$ & $77^{\circ} 25^{\prime}$ \\
\hline 20 & Poonthampanai & Poon & C-4 & 1 & 1300 & $11^{\circ} 12^{\prime}$ & $77^{\circ} 26^{\prime}$ \\
\hline 21 & Santhamparai near bridge & San-bridge & $\mathrm{C}-5$ & 2 & 1350 & $11^{\circ} 00^{\prime}$ & $77^{\circ} 52^{\prime}$ \\
\hline 22 & Santhamparai near SDA school & San-SDA & $\mathrm{C}-6$ & 4 & 1400 & $11^{\circ} 13^{\prime}$ & $77^{\circ} 28^{\prime}$ \\
\hline 23 & Mattupetty Dam stream & Matt & $\mathrm{C}-7$ & 2 & 1700 & $11^{\circ} 16^{\prime}$ & $77^{\circ} 29^{\prime}$ \\
\hline 24 & Anayirankal stream & Anai & $\mathrm{C}-8$ & 2 & 1950 & $11^{\circ} 18^{\prime}$ & $77^{\circ} 31^{\prime}$ \\
\hline 25 & Aranmanaiparai & Aran & C-9 & 3 & 2050 & $11^{\circ} 21^{\prime}$ & $77^{\circ} 33^{\prime}$ \\
\hline 26 & Popparai & Popp & $\mathrm{C}-10$ & 4 & 1785 & $11^{\circ} 44^{\prime}$ & $77^{\circ} 26^{\prime}$ \\
\hline 27 & Bodimettu & Bodi & $\mathrm{C}-11$ & 2 & 1500 & $11^{\circ} 15^{\prime}$ & $77^{\circ} 24^{\prime}$ \\
\hline 28 & Thoovanam falls & Thuv & $\mathrm{C}-12$ & 3 & 1550 & $11^{\circ} 15^{\prime}$ & $77^{\circ} 15^{\prime}$ \\
\hline 29 & Nayamakkadu falls & Naya & $\mathrm{C}-13$ & 2 & 2197 & $11^{\circ} 20^{\prime}$ & $77^{\circ} 10^{\prime}$ \\
\hline 30 & Chinnakanal falls & Chin & $\mathrm{C}-14$ & 1 & 1800 & $11^{\circ} 27^{\prime}$ & $77^{\circ} 30^{\prime}$ \\
\hline
\end{tabular}


Table 2. Species of Mayflies in Palni hills

\begin{tabular}{|c|c|c|c|c|c|c|c|c|c|c|c|c|c|c|c|c|c|c|}
\hline ORDER & FAMILY & GENUS AND SPECIES & 1 & 2 & 3 & 4 & 5 & 6 & 7 & 8 & 9 & 10 & 11 & 12 & 13 & 14 & 15 & 16 \\
\hline & & & Ooth & Peru & Kuru & Gand & Silv & Vatt & Fair & Bear & Fern & Pill & Near pill & Pamb & Dhob & Gund & Poom & Koun \\
\hline & Baetidae & Baetis acceptus & 11 & 12 & 8 & 31 & 11 & 19 & 22 & 19 & 27 & 17 & 11 & 17 & 17 & 24 & 30 & 17 \\
\hline & & Baetis conservatus & 8 & 17 & 11 & 11 & 8 & 21 & 18 & 11 & 17 & 20 & 23 & 22 & 18 & 26 & 19 & 32 \\
\hline & & Tenuibaetis frequentus & 12 & 21 & 22 & 8 & 17 & 43 & 52 & 29 & 29 & 33 & 42 & 32 & 20 & 42 & 17 & 42 \\
\hline & & Baetis ordinates & 8 & 11 & 5 & 0 & 0 & 0 & 14 & 5 & 10 & 5 & 10 & 19 & 10 & 27 & 42 & 12 \\
\hline & & Labiobaetis geminatus & 5 & 7 & 11 & 11 & 17 & 45 & 29 & 28 & 17 & 7 & 5 & 8 & 0 & 42 & 29 & 32 \\
\hline \multirow[t]{21}{*}{ Ephemeroptera } & & Centroptella similis & 12 & 11 & 20 & 21 & 17 & 46 & 23 & 17 & 12 & 11 & 0 & 21 & 0 & 0 & 17 & 14 \\
\hline & & Centroptella ceylonensis & 0 & 0 & 0 & 0 & 0 & 0 & 0 & 0 & 0 & 0 & 0 & 0 & 0 & 0 & 0 & 0 \\
\hline & & Acentrella vera & 0 & 0 & 0 & 0 & 0 & 0 & 0 & 0 & 0 & 0 & 0 & 0 & 12 & 11 & 0 & 11 \\
\hline & Heptageniidae & Afronurus $s p$. & 26 & 0 & 0 & 22 & 0 & 0 & 0 & 0 & 0 & 0 & 0 & 0 & 34 & 41 & 0 & 0 \\
\hline & & Afronurus kumbakkaraiensis & 0 & 0 & 0 & 0 & 0 & 0 & 0 & 0 & 0 & 0 & 0 & 0 & & 0 & 0 & 0 \\
\hline & & Epeorus petersi & 0 & 0 & 0 & 0 & 0 & 0 & 0 & 0 & 0 & 10 & 0 & 0 & 0 & 26 & 0 & 0 \\
\hline & & Thalerosphyrus flowersi & 0 & 0 & 0 & 0 & 0 & 0 & 0 & 0 & 0 & 0 & 0 & 0 & 0 & 0 & 33 & 0 \\
\hline & Leptophlebiidae & Choroterpes alagarensis & 22 & 18 & 0 & 47 & 41 & 39 & 52 & 37 & 23 & 47 & 32 & 38 & 65 & 27 & 0 & 35 \\
\hline & & Edmundsula lotica & 0 & 0 & 17 & 10 & 0 & 33 & 29 & 27 & 15 & 53 & 62 & 31 & 24 & 17 & 17 & 33 \\
\hline & & Indialis badia & 0 & 0 & 0 & 0 & 0 & 0 & 0 & 0 & 0 & 0 & 0 & 0 & 0 & 0 & 15 & 13 \\
\hline & & Isca purpurea & 24 & 19 & 21 & 25 & 41 & 43 & 21 & 26 & 37 & 27 & 18 & 23 & 36 & 28 & 0 & 39 \\
\hline & & Nathanella indica & 10 & 5 & 17 & 0 & 0 & 0 & 19 & 22 & 27 & 0 & 5 & 11 & 0 & 0 & 0 & 0 \\
\hline & & Notophlebia jobi & 5 & 0 & 11 & 0 & 23 & 16 & 6 & 17 & 17 & 7 & 0 & 23 & 0 & 0 & 21 & 0 \\
\hline & & Petersula courtallensis & 15 & 0 & 0 & 20 & 17 & 18 & 14 & 10 & 18 & 11 & 11 & 10 & 17 & 14 & 17 & 0 \\
\hline & Neoephemeridae & Potamanthellus ganges & 0 & 0 & 0 & 0 & 0 & 0 & 0 & 0 & 0 & 0 & 0 & 0 & 0 & 0 & 5 & 0 \\
\hline & & Thraulus gopalani & 0 & 0 & 6 & 4 & 0 & 8 & 5 & 9 & 0 & 0 & 13 & 21 & 0 & 0 & 21 & 0 \\
\hline & Teloganodidae & Teloganodes dentata & 11 & 8 & 17 & 14 & 17 & 11 & 8 & 21 & 14 & 24 & 19 & 12 & 19 & 0 & 32 & 32 \\
\hline & & Teloganodes kodai & 17 & 14 & 8 & 27 & 14 & 21 & 22 & 23 & 33 & 16 & 62 & 42 & 0 & 0 & 27 & 28 \\
\hline & & Teloganodes insignis & 13 & 6 & 15 & 8 & 19 & 0 & 0 & 0 & 0 & 14 & 5 & 45 & 52 & 38 & 54 & 0 \\
\hline & Ephemeridae & Ephemera nadinae & 0 & 0 & 0 & 0 & 0 & 0 & 0 & 0 & 0 & 0 & 0 & 0 & 0 & 0 & 0 & 52 \\
\hline & Caenidae & Caenis sp. & 32 & 14 & 8 & 10 & 27 & 12 & 21 & 32 & 29 & 13 & 18 & 7 & 8 & 12 & 29 & 36 \\
\hline
\end{tabular}


Table 3. Species of Mayflies in Cardamom hills

\begin{tabular}{|c|c|c|c|c|c|c|c|c|c|c|c|c|c|c|c|c|}
\hline ORDER & FAMILY & GENUS AND SPECIES & 17 & 18 & 19 & 20 & 21 & 22 & 23 & 24 & 25 & 26 & 27 & 28 & 29 & 30 \\
\hline & & & Kura-up & Kura- down & B.L.Rave & Poon & San-bridge & San-SDA & Matt & Anai & Aran & Popp & Bodi & Thuv & Naya & Chin \\
\hline & Baetidae & Baetis acceptus & 0 & 0 & 17 & 17 & 0 & 0 & 0 & 42 & 0 & 0 & 22 & 0 & 41 & 12 \\
\hline & & Baetis conservatus & 0 & 0 & 11 & 15 & 0 & 0 & 0 & 31 & 0 & 19 & 0 & 12 & 29 & 32 \\
\hline & & Tenuibaetis frequentus & 42 & 21 & 29 & 42 & 13 & 21 & 32 & 31 & 17 & 23 & 33 & 27 & 17 & 27 \\
\hline & & Labiobaetis geminatus & 32 & 17 & 21 & 41 & 0 & 39 & 32 & 42 & 17 & 10 & 17 & 27 & 37 & 41 \\
\hline \multirow[t]{19}{*}{ Ephemeroptera } & & Centroptella similis & 37 & 21 & 17 & 31 & 34 & 13 & 33 & 27 & 0 & 15 & 16 & 22 & 0 & 30 \\
\hline & & Centroptella ceylonensis & 0 & 0 & 16 & 34 & 5 & 25 & 29 & 0 & 11 & 0 & 0 & 0 & 17 & 0 \\
\hline & & Acentrella vera & 0 & 0 & 25 & 0 & 0 & 30 & 31 & 0 & 0 & 21 & 32 & 0 & 0 & 0 \\
\hline & & Afronurus kumbakkaraiensis & 37 & 17 & 42 & 42 & 15 & 19 & 47 & 37 & 33 & 32 & 21 & 37 & 29 & 33 \\
\hline & & Epeorus petersi & 31 & 20 & 33 & 27 & 23 & 22 & 31 & 33 & 12 & 42 & 32 & 33 & 37 & 12 \\
\hline & & Thalerosphyrus flowersi & 47 & 28 & 0 & 0 & 0 & 0 & 0 & 0 & 0 & 33 & 14 & 0 & 0 & 0 \\
\hline & Leptophlebiidae & Choroterpes alagarensis & 62 & 32 & 52 & 21 & 33 & 41 & 21 & 35 & 27 & 55 & 32 & 41 & 24 & 32 \\
\hline & & Edmundsula lotica & 0 & 0 & 0 & 0 & 16 & 17 & 31 & 0 & 31 & 32 & 37 & 33 & 23 & 27 \\
\hline & & Indialis badia & 23 & 32 & 0 & 0 & 0 & 0 & 0 & 29 & 0 & 0 & 0 & 0 & 0 & 0 \\
\hline & & Isca purpurea & 5 & 0 & 15 & 33 & 21 & 55 & 36 & 44 & 32 & 17 & 13 & 31 & 21 & 30 \\
\hline & & Nathanella indica & 32 & 17 & 0 & 0 & 0 & 28 & 0 & 0 & 0 & 0 & 0 & 0 & 0 & 21 \\
\hline & & Notophlebia jobi & 13 & 11 & 27 & 13 & 14 & 10 & 19 & 0 & 35 & 27 & 20 & 27 & 30 & 21 \\
\hline & & Petersula courtallensis & 10 & 15 & 0 & 0 & 0 & 0 & 23 & 27 & 34 & 32 & 15 & 13 & 11 & 0 \\
\hline & & Thraulus gopalani & 17 & 11 & 0 & 0 & 0 & 0 & 0 & 0 & 25 & 0 & 0 & 0 & 5 & 0 \\
\hline & Teloganodidae & Teloganodes dentata & 0 & 0 & 0 & 27 & 21 & 18 & 0 & 16 & 20 & 19 & 27 & 0 & 27 & 23 \\
\hline & & Teloganodes kodai & 0 & 0 & 0 & 0 & 23 & 21 & 43 & 0 & 34 & 0 & 14 & 17 & 10 & 0 \\
\hline & & Teloganodes insignis & 0 & 0 & 0 & 0 & 17 & 17 & 0 & 0 & 25 & 0 & 0 & 0 & 0 & 0 \\
\hline & Ephemeridae & Ephemera nadinae & 98 & 5 & 0 & 0 & 0 & 0 & 0 & 0 & 0 & 0 & 0 & 0 & 0 & 0 \\
\hline & Caenidae & Caenis sp. & 27 & 42 & 42 & 33 & 17 & 29 & 21 & 32 & 19 & 31 & 0 & 23 & 39 & 31 \\
\hline
\end{tabular}




\section{Results and Discussion}

\section{PCA Analysis of Palni Hills}

Based on the scree plot results, three components were chosen in both Palni and Cardamom hills. PCA of Palni hills identified three principle components of water quality measures that explained $80.05 \%$ of the variation (Table 4) in water quality between streams. Figure 1 shows the PCA of Palni hills. PCA analysis of Palni hills categorize the sites into three groups which are referred as components namely component 1, component 2 and component 3 .

Component 1 is positively correlated with the parameters like water temperature, air temperature and dissolved oxygen (DO), velocity and width of the stream (Figure 2), $\mathrm{pH}$ and hardness are not supporting these sites. The sites included in this component are Oothu, Fairy falls, Vattakanal, Perumalmalai, Kurusadai and Bear chola. In this component Perumalmalai is distantly placed.

The study sites in component 2 are Dhobikana, Poomparai and Pambar are highly correlated with Hardness, alkalinity, water temperature, air temperature and width of the stream (Figure 3). $\mathrm{pH}$, conductivity, $\mathrm{DO}$ and $\mathrm{BOD}$ are negatively correlated with the component 2 sites. In this component,
Dhobikana and Poomparai are distantly placed. Component 3 (Figure 4) includes Silvercascade, Kounchi, Pillar rock, near pillar rock, Fern hill, Gundar and Ghandhinagar. Here $\mathrm{pH}$, water temperature, air temperature, conductivity, width and TDS are highly positively correlated whereas DO, velocity, hardness, alkalinity and BOD are negatively correlated. Fern hill is placed away from other sites.

Table 4. Variance explained and the eigen values for the physico-chemical variables of Palni hills

\begin{tabular}{|c|c|c|}
\hline Axis & Eigen value & \% Variance \\
\hline 1 & $\mathbf{2 . 9 4 8 4 9}$ & $\mathbf{2 6 . 8 0 4}$ \\
\hline 2 & $\mathbf{2 . 5 2 7 8}$ & $\mathbf{2 2 . 9 8}$ \\
\hline 3 & $\mathbf{1 . 8 6 7 7 4}$ & $\mathbf{1 6 . 9 7 9}$ \\
\hline 4 & $\mathbf{1 . 2 3 6 1 2}$ & $\mathbf{1 1 . 2 3 7}$ \\
\hline 5 & 0.904433 & 8.2221 \\
\hline 6 & 0.722309 & 6.5664 \\
\hline 7 & 0.422977 & 3.8452 \\
\hline 8 & 0.210023 & 1.9093 \\
\hline 9 & 0.088112 & 0.80101 \\
\hline 10 & 0.069933 & 0.63575 \\
\hline 11 & 0.002067 & 0.018794 \\
\hline
\end{tabular}

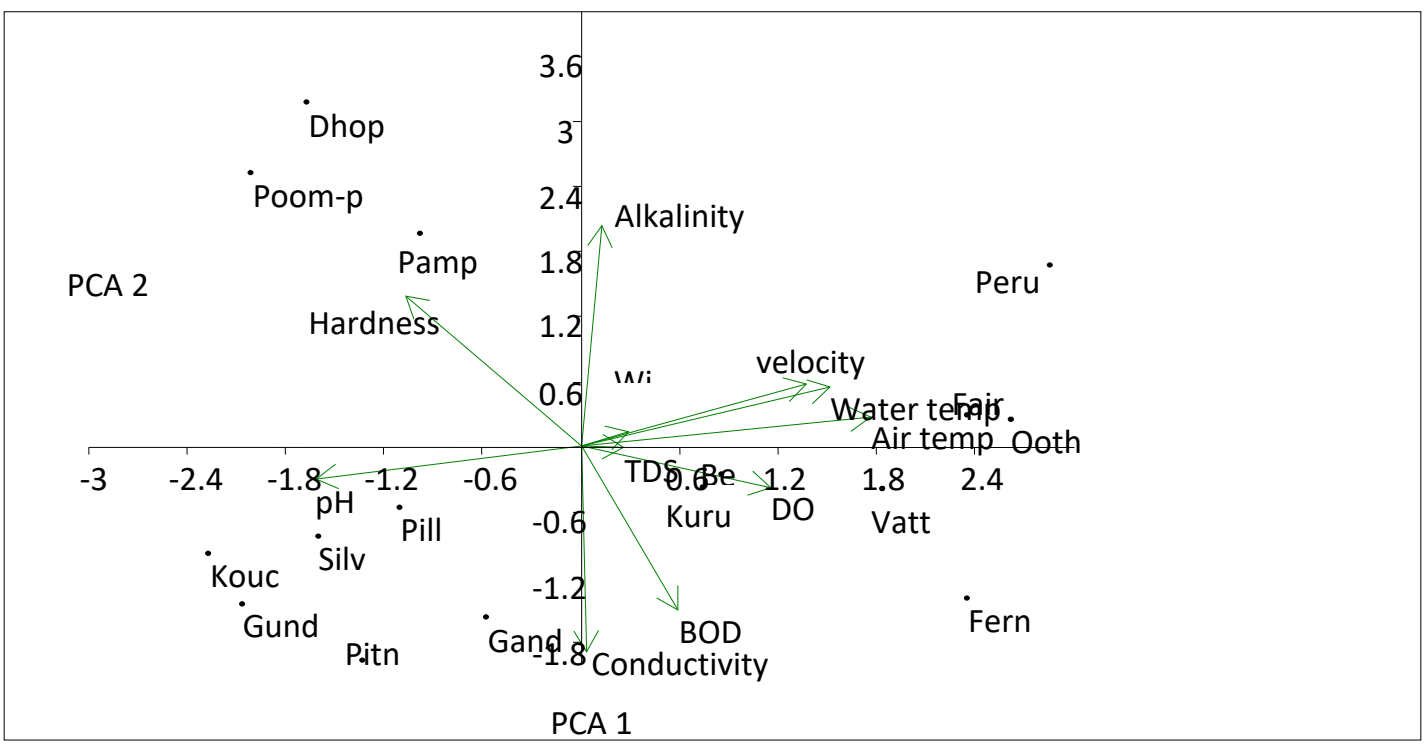

Figure 1. Principal component Analysis for Palni hills 


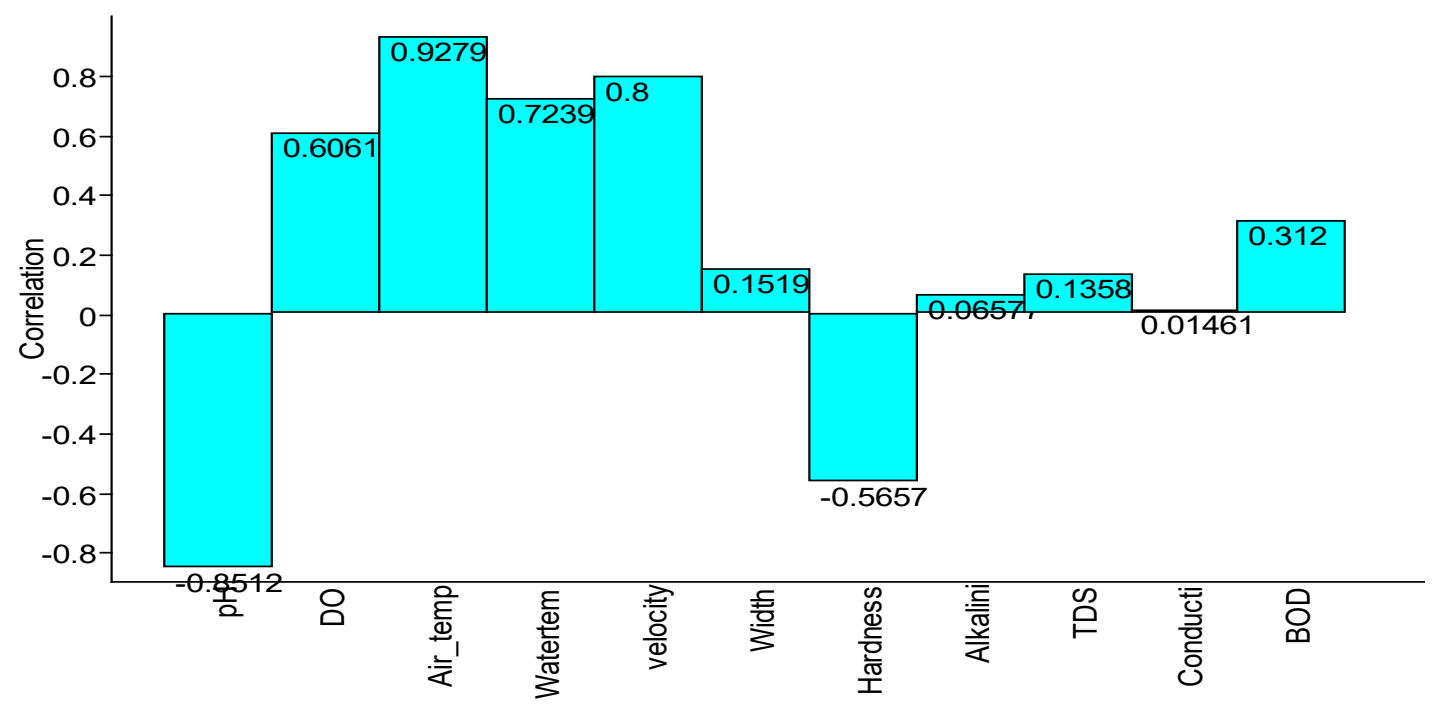

Figure 2. Component 1 of PCA in Palni hills

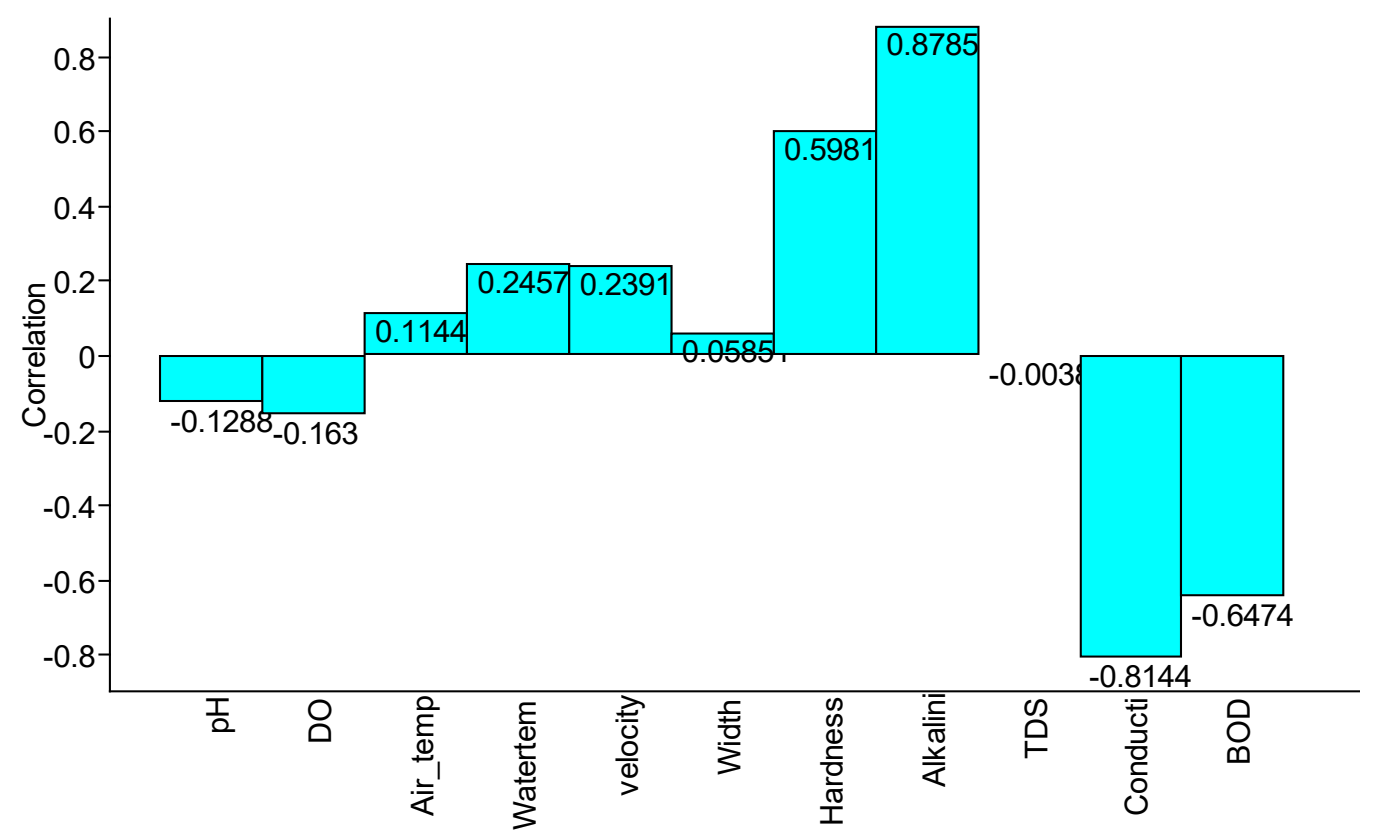

Figure 3. Component 2 of PCA in Palni hills 


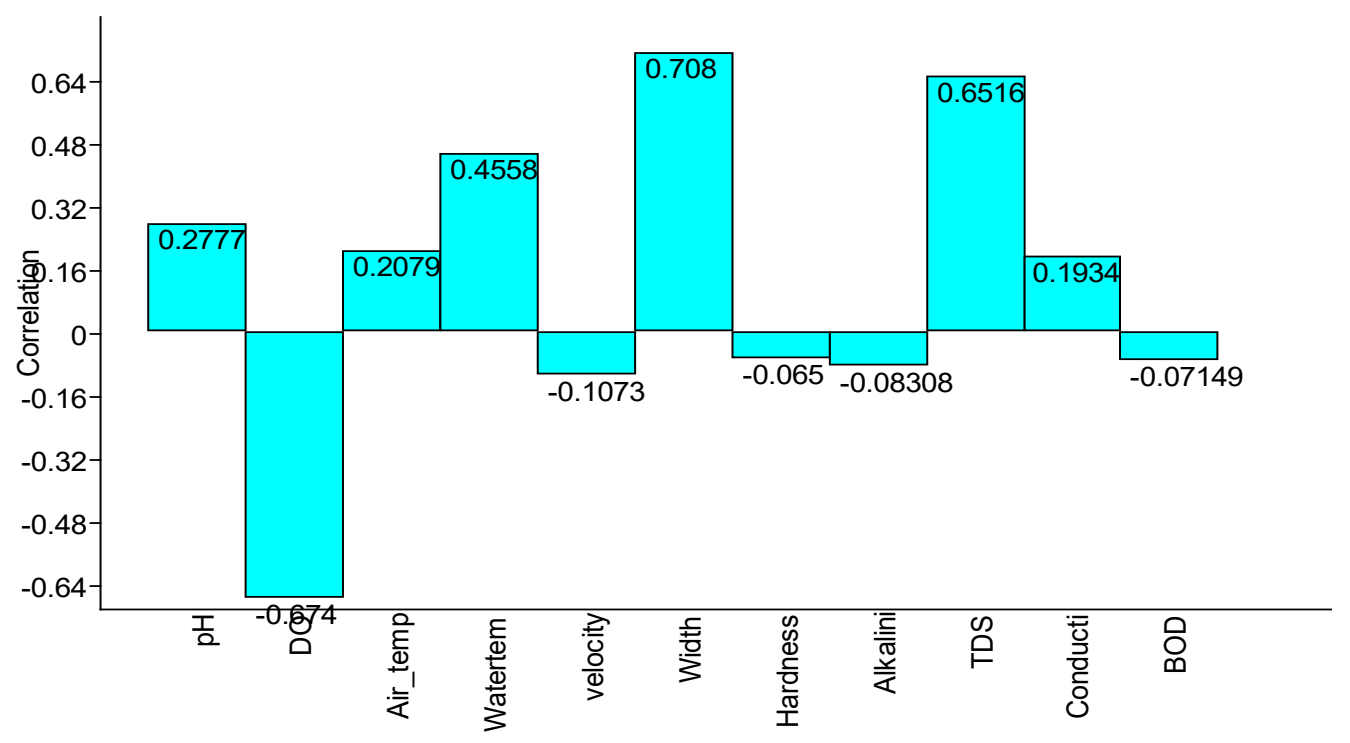

Figure 4. Component 3 of PCA in Palni hills

\section{PCA Analysis of Cardamom Hills}

PCA for Cardamom hill is shown in Figure 5. The first three components of the PCA for physicochemical parameters at the sites collectively explained $77 \%$ of the variability at these sites (Table 5).

In component 1 (Figure 6) DO, air temperature, water temperature, hardness, alkalinity, TDS, conductivity and BOD are positively correlated with the sites Popparai, Poonthampanai, Bodimettu, Anayirangal, Chinnakanal, Aranmanaiparai and Mattupatti. But these sites are negatively correlated with $\mathrm{pH}$, velocity and width of the stream. Supporting factors of component 2 (Figure 7) are $\mathrm{pH}$, velocity, width of the stream, hardness, BOD and alkalinity. Air temperature, water temperature, DO, TDS and conductivity are negatively correlated to the site Nayamakkadu. Nayamakkadu alone is placed under component 2 .

Figure 8 representing component 3 shows that all the parameters are highly positively correlated with the sites. The sites included in this component are Kurangani up, Kurangani down, Thoovanam, B. L. Rave, Santhamparai SDA and Santhamparai near bridge. The site Santhamparai near bridge is plotted far away in the third components.
Table 5. Variance explained and the eigenvalues for the physico-chemical variables of Cardamom hills

\begin{tabular}{|c|c|c|}
\hline Axis & Eigen value & \% Variance \\
\hline 1 & $\mathbf{3 . 5 8 0 3 5}$ & $\mathbf{3 2 . 5 4 9}$ \\
\hline 2 & $\mathbf{2 . 3 8 9 0 3}$ & $\mathbf{2 1 . 7 1 8}$ \\
\hline 3 & $\mathbf{1 . 7 7 3 2 7}$ & $\mathbf{1 6 . 1 2 1}$ \\
\hline 4 & $\mathbf{1 . 0 6 3 6 9}$ & $\mathbf{9 . 6 6 9 9}$ \\
\hline 5 & 0.880061 & 8.0006 \\
\hline 6 & 0.468153 & 4.2559 \\
\hline 7 & 0.416393 & 3.7854 \\
\hline 8 & 0.222051 & 2.0186 \\
\hline 9 & 0.118548 & 1.0777 \\
\hline 10 & 0.062119 & 0.56472 \\
\hline 11 & 0.026342 & 0.23947 \\
\hline
\end{tabular}




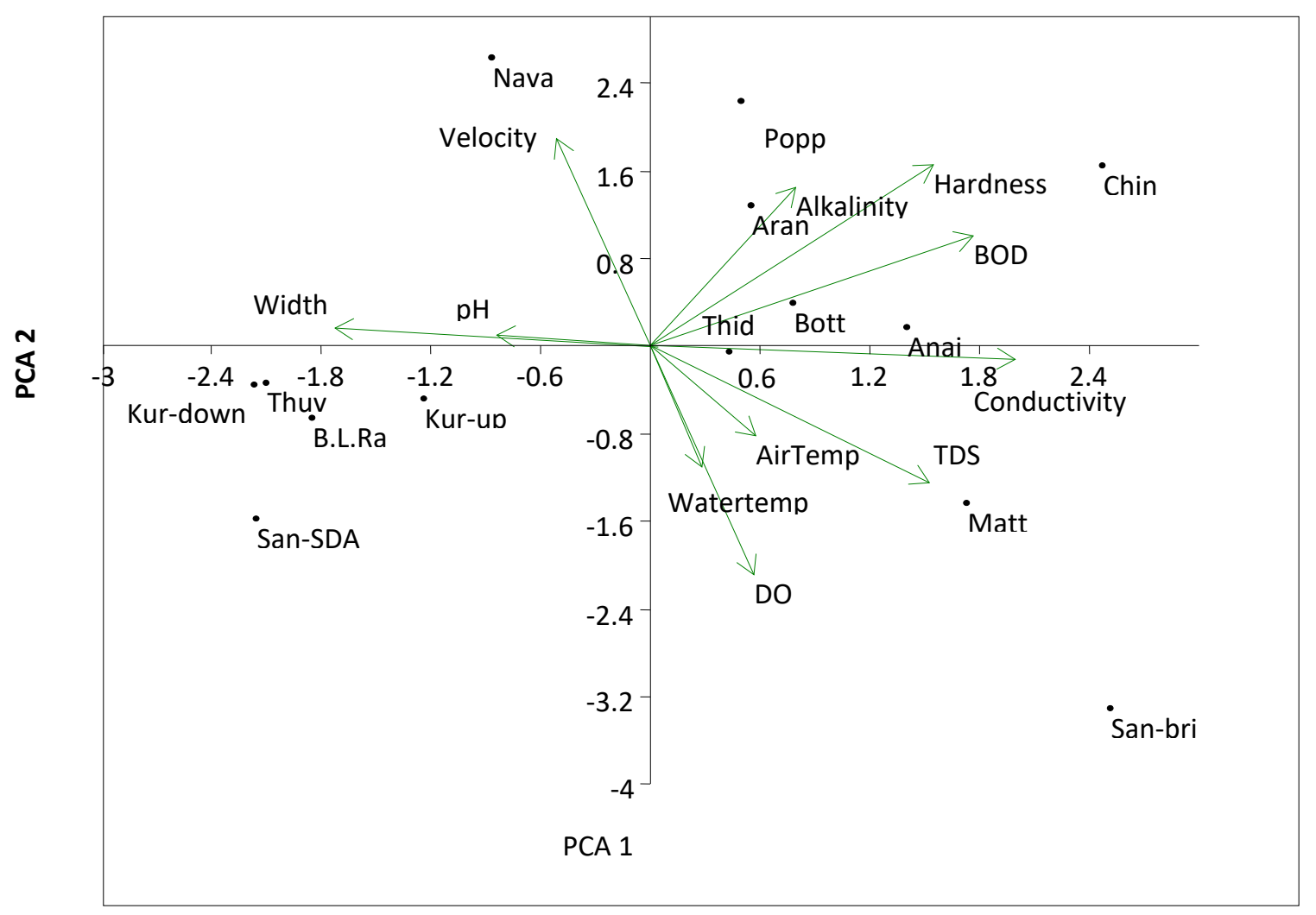

Figure 5. Principal component Analysis for Cardamom hills

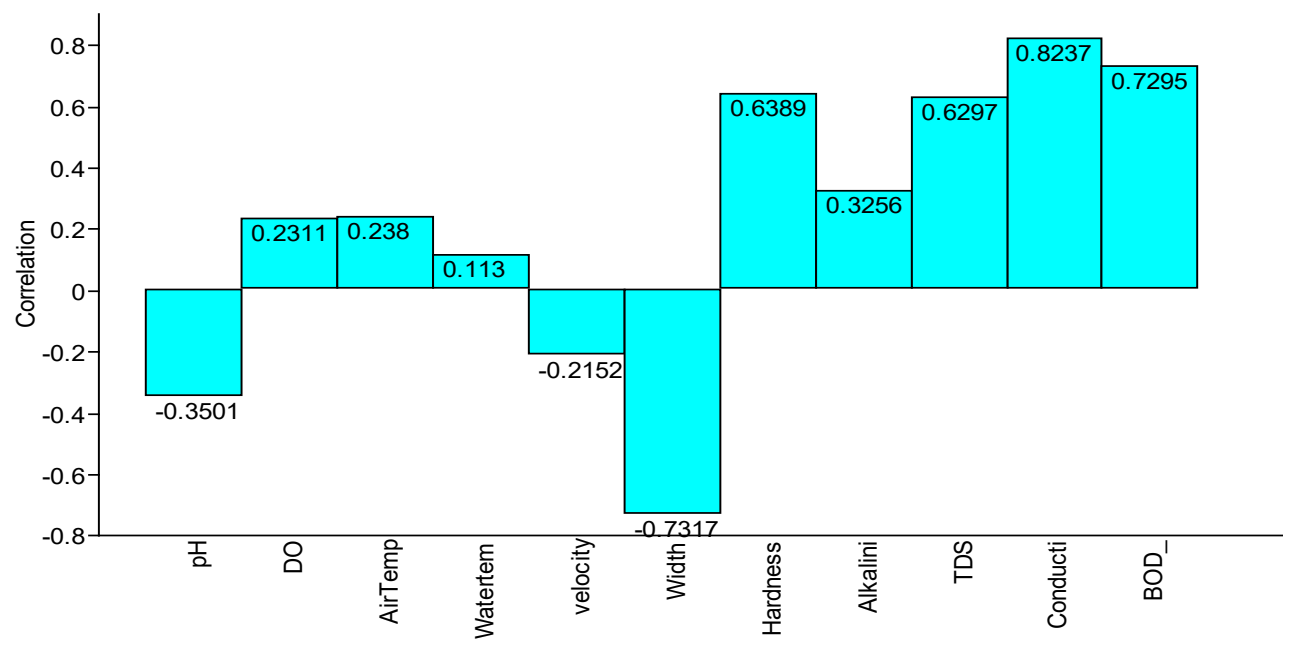

Figure 6. Component 1 of PCA in Cardamom hills 


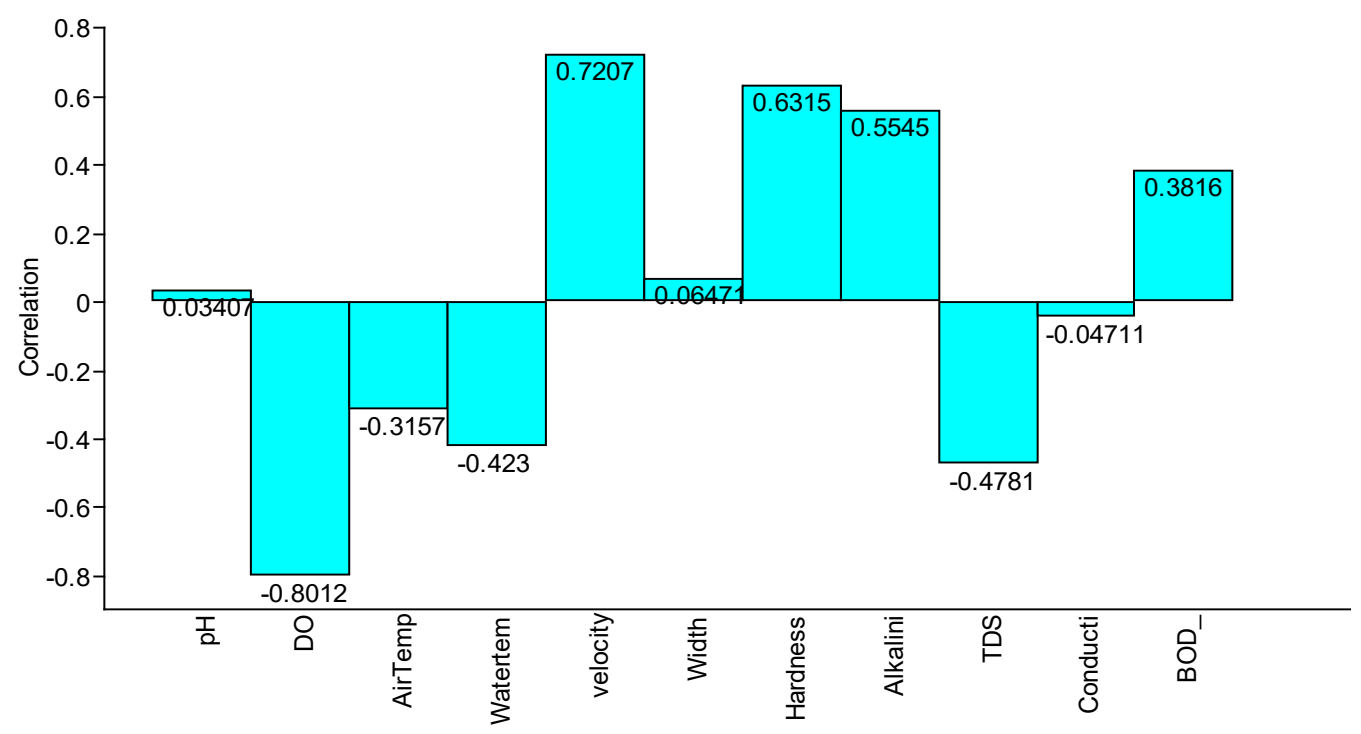

Figure 7. Component 2 of PCA in Cardamom hills

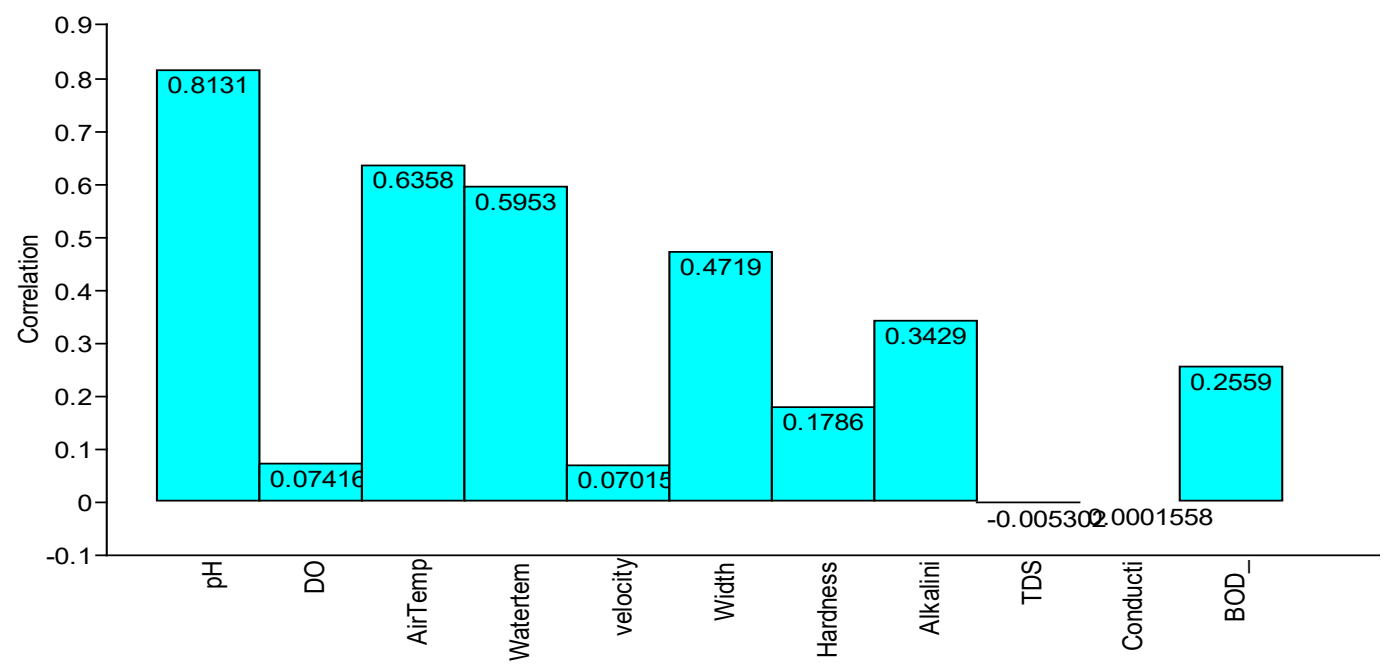

Figure 8. Component 3 of PCA in Cardamom hills 


\section{pH}

Mayfly nymphs are sensitive to low $\mathrm{pH}$. In Palni hills components 1 and 2 are negatively correlated with $\mathrm{pH}$ whereas, component three is positively correlated. The $\mathrm{pH}$ of the sites ranges between 6.3-7.52 (Table 6). Due to anthropogenic impacts, the $\mathrm{pH}$ is slightly acidic in certain sites like Vattakanal. Streams typically have a slightly basic $\mathrm{pH}$ value ranging from 7 to 8 . Most organisms have optimal $\mathrm{pH}$ ranges in which they live that fall between 6 and 8 (Campbell and Wildberger, 2001). Even slight changes in the normal $\mathrm{pH}$ can have considerable effects on mayflies. In cardamom hills except component 1 the other two components are negatively correlated with $\mathrm{pH}$. In this hill the $\mathrm{pH}$ ranges 6.0 to 7.4 (Table 7).

\section{Dissolved Oxygen}

The standard levels indicate that Dissolved Oxygen (DO) $4-$ $7 \mathrm{mg} / \mathrm{l}$ is good for mayflies (Payne, 1986). DO plays a vital role in supporting aquatic life and is susceptible to slight environment changes and hence DO have been extensively used as a parameter delineating water quality and to evaluate the degree of freshness of a river (Fakayode, 2005). DO is positively correlated with component 1 of Palni and Components 1 and 3 are positively correlated in Cardamom hills. The DO in the sites was found within the range (4 -7.7 mg/L) (Table $6)$.

\section{Water Temperature and Air Temperature}

Based on the earlier works it is understood that the positive correlation with the water temperature and air temperature plays a major role in maintaining the number of organisms. The PCA results of both the hills show positive correlation for Water temperature and air temperature except component 2 in cardamom hills.

\section{Alkalinity}

Total alkalinity of water is due to presence of mineral salt present in it. It is primarily caused by the carbonate and bicarbonate ions. Levels of alkalinity between 100 and 200 $\mathrm{mg} / \mathrm{L}$ provide ideal buffering within a stream. But it has the permissible limit up to $600 \mathrm{mg} / \mathrm{L}$. In the present study the alkalinity falls under the permissible limit $(345-367 \mathrm{mg} / \mathrm{L})$. Among both the hills alkalinity show positive relation with all components except Component 3 of Palni hills.

\section{Total Dissolved Solids (TDS)}

Total Dissolved Solid is a measurement of inorganic salts, organic matter and other dissolved materials in water, TDS above $1340 \mathrm{mg} / \mathrm{l}$ may adversely affect mayflies (Good fellow et al., 2000; SETAC, 2004). TDS and the associated elevated conductivity seem to be particularly toxic and stressor to mayfly community in the streams (Pond et al., 2008). In the present study TDS is highly correlated with all the components.

\section{Hardness}

Total hardness is used to describe the effect of dissolved minerals (mostly $\mathrm{Ca}$ and $\mathrm{Mg}$ ). Optimal values of hardness of aquatic life range from 100 to $200 \mathrm{mg} / \mathrm{L}$. At levels above 250 $\mathrm{mg} / \mathrm{L}$, calcium carbonate will begin to precipitate. According to the results, hardness is negatively correlated with components 1 and 3 in Palni hills, and in Cardamom hills it is positively correlated with all the sites. The high value of total hardness may be due to discharge of sewage from nearby places, use of soaps and detergents by laundries, washing, bathing by people.

\section{Biological Oxygen Demand (BOD)}

Healthy streams which have BOD reading of less than $2 \mathrm{mg} / \mathrm{l}$, whereas polluted streams is of $10 \mathrm{mg} / \mathrm{L}$. In components 2 and 3 in Palni hills, the BOD is negatively correlated and the other components are positively correlated.

\section{Conductivity}

Most streams ranges between 50 to $1500 \mu \mathrm{S} / \mathrm{cm}$. Ideal levels of conductivity for the mayfly richness ranges 150 to 500 $\mu \mathrm{S} / \mathrm{cm}$. In the study sites, components 2 of both the hills are negatively correlated.

\section{Velocity and Stream Width}

Velocity is correlated positively except component 3 for Palni hills and component 1 of Cardamom hills. Stream width is positively correlated except component 1 of Palni hills.

\section{CCA Analysis}

The relationship between the mayfly's communities and the environmental parameters was depicted by CCA (Canonical Correspondence Analysis). For CCA analysis, eleven environmental variables were used. Figure 9 shows the result of ordination of sites and Ephemeroptera with respect to environmental variables in Palni hills. From the outcomes, the destinations P-1, P-4, P-11, P-13, P-14 and P-16 were found away from the referenced ecological factors and were influenced by anthropogenic action and slightly polluted. The sites P-2, P-3, P-5, P-6 P-7, P-8, P-9 and P-10 were decidedly connected with factors like air temperature, water temperature, DO, BOD, TDS, conductivity and current speed whereas it is it is contrarily related with $\mathrm{pH}$, altitude, hardness and alkalinity. Sites include P-12 and P-15 were positively correlated with $\mathrm{pH}$, altitude, hardness and alkalinity and adversely related with air temperature, water temperature, DO, BOD, TDS, current speed and conductivity. 
Table 6. Physico-chemical features, water quality parameters of the sampling sites in Palni hills

\begin{tabular}{|c|c|c|c|c|c|c|c|c|c|c|c|c|}
\hline S. No & Site & pH & $\begin{array}{c}\text { D.O } \\
(\mathrm{mg} / \mathrm{L})\end{array}$ & $\begin{array}{l}\text { Air temp } \\
\left({ }^{\circ} \mathrm{C}\right)\end{array}$ & $\begin{array}{c}\text { Water temp } \\
\left({ }^{\circ} \mathrm{C}\right)\end{array}$ & $\begin{array}{c}\text { Current speed } \\
\left(\sec \mathrm{m}^{-1}\right)\end{array}$ & $\begin{array}{c}\text { Width } \\
\text { (m) }\end{array}$ & $\begin{array}{c}\text { Hardness } \\
(\mathrm{mg} / \mathrm{L})\end{array}$ & $\begin{array}{c}\text { Alkalinity } \\
\text { (mg/L) }\end{array}$ & $\begin{array}{c}\text { Total dissolved } \\
\text { solids (ppt) }\end{array}$ & $\begin{array}{c}\text { Conductivity } \\
(\mu \mathrm{s} / \mathrm{cm})\end{array}$ & $\begin{array}{c}\text { BOD } \\
(\mathrm{mg} / \mathrm{L})\end{array}$ \\
\hline 1 & Ooth & 6.8 & 4.6 & 18.7 & 15 & 11 & $6-7$ & 73 & 342 & 0.132 & 108 & 2.3 \\
\hline 2 & Peru & 6.3 & 4.7 & 18.3 & 15.4 & 11 & $2-3$ & 87 & 342 & 0.099 & 79 & 2.45 \\
\hline 3 & Kuru & 7.3 & 4.2 & 17.7 & 16 & 6 & $2.5-3$ & 83 & 312 & 0.089 & 87 & 3.88 \\
\hline 4 & Gand & 7.35 & 4.3 & 16 & 14 & 5 & $2-3$ & 90 & 288 & 0.093 & 112 & 2.65 \\
\hline 5 & Silv & 7.36 & 4.2 & 15.7 & 13.4 & 3 & $5-10$ & 98 & 299 & 0.084 & 103 & 2.34 \\
\hline 6 & Vatt & 6.3 & 4.9 & 18.3 & 14 & 5 & $1-2$ & 85 & 321 & 0.079 & 102 & 2.53 \\
\hline 7 & Fair & 6.5 & 4.4 & 19.7 & 16.1 & 9 & $1-2$ & 94 & 314 & 0.083 & 97 & 2.78 \\
\hline 8 & Bear & 7.1 & 4 & 18.9 & 15 & 6 & $2-3$ & 85 & 323 & 0.769 & 110 & 2.57 \\
\hline 9 & Fern & 6.5 & 4.8 & 19 & 14.6 & 8 & $1-2$ & 102 & 312 & 0.094 & 125 & 4.12 \\
\hline 10 & Pill & 7.47 & 4.4 & 15 & 11.4 & 6 & $0.5-1$ & 90 & 343 & 0.122 & 105 & 3.23 \\
\hline 11 & Near pill & 7.4 & 4.5 & 15.4 & 10 & 6 & $1-2$ & 92 & 288 & 0.093 & 112 & 2.65 \\
\hline 12 & Pamb & 6.9 & 4.3 & 15.8 & 13.2 & 5 & $2-3$ & 112 & 345 & 0.098 & 93 & 1.3 \\
\hline 13 & Dhob & 7.52 & 4 & 16.3 & 14.1 & 6 & $1-2$ & 156 & 367 & 0.085 & 76 & 2.32 \\
\hline 14 & Gund & 7.45 & 4 & 14.5 & 13 & 4 & $4-6$ & 107 & 304 & 0.097 & 126 & 2.87 \\
\hline 15 & Poom & 7.25 & 4.3 & 15.4 & 12 & 5 & $2-3$ & 143 & 353 & 0.112 & 88 & 1.4 \\
\hline 16 & Kouc & 7.3 & 4.4 & 14 & 10.5 & 4 & $0.25-0.5$ & 94 & 314 & 0.083 & 97 & 2.78 \\
\hline
\end{tabular}

Table 7. Physico-chemical features, water quality parameters of the sampling sites in Cardamom hills

\begin{tabular}{|c|c|c|c|c|c|c|c|c|c|c|c|c|}
\hline S. No & Site & $\mathbf{P h}$ & $\begin{array}{c}\text { D.O } \\
(\mathrm{mg} / \mathrm{L})\end{array}$ & $\begin{array}{c}\text { Air Temp } \\
\left({ }^{\circ} \mathrm{C}\right)\end{array}$ & $\begin{array}{c}\text { Water temp } \\
\left({ }^{\circ} \mathrm{C}\right)\end{array}$ & $\begin{array}{c}\text { Current speed } \\
\left(\operatorname{sec~m}^{-1}\right)\end{array}$ & $\begin{array}{c}\text { Width } \\
\text { (m) }\end{array}$ & $\begin{array}{c}\text { Hardness } \\
(\mathrm{mg} / \mathrm{L})\end{array}$ & $\begin{array}{c}\text { Alkalinity } \\
\text { (mg/L) }\end{array}$ & $\begin{array}{c}\text { Total dissolved } \\
\text { solids (ppt) }\end{array}$ & $\begin{array}{c}\text { Conductivity } \\
(\mu \mathrm{s} / \mathrm{cm})\end{array}$ & $\begin{array}{c}\text { BOD } \\
(\mathrm{mg} / \mathrm{L})\end{array}$ \\
\hline 1 & Kura-up & 6 & 6.7 & 21 & 18.5 & $3-4$ & 10 & 72 & 312 & 0.077 & 80 & 1.74 \\
\hline 2 & Kura-down & 7.3 & 6.4 & 22 & 18.4 & $4-5$ & 11 & 82 & 267 & 0.089 & 79 & 1.32 \\
\hline 3 & B.L.Rave & 7.2 & 6.3 & 23 & 19.1 & $4-6$ & 8 & 48 & 333 & 0.082 & 92 & 0.89 \\
\hline 4 & Poon & 7.4 & 6 & 22 & 20.2 & $3-4$ & 10 & 94 & 384 & 0.132 & 108 & 2.3 \\
\hline 5 & San-bridge & 6.5 & 7.7 & 23 & 18.3 & $2-3$ & 5 & 87 & 267 & 0.688 & 124 & 1.65 \\
\hline 7 & San-SDA & 7.4 & 6.8 & 23 & 20.2 & $4-5$ & 11 & 55 & 237 & 0.073 & 86 & 1.54 \\
\hline 6 & Matt & 6.4 & 7.4 & 24 & 19.1 & $3-4$ & 4 & 89 & 306 & 0.129 & 105 & 2.65 \\
\hline 8 & Anai & 7.1 & 7.4 & 24 & 20.3 & $3-4$ & 8 & 173 & 435 & 0.1 & 89 & 3.46 \\
\hline 9 & Aran & 6.5 & 6 & 23 & 16.5 & $4-6$ & 7 & 102 & 354 & 0.093 & 106 & 2.32 \\
\hline 10 & Popp & 7.5 & 5.2 & 23 & 18.4 & $5-6$ & 12 & 156 & 345 & 0.098 & 105 & 4.32 \\
\hline 11 & Bodi & 6.4 & 6.5 & 20 & 19.4 & $4-5$ & 4 & 98 & 299 & 0.084 & 103 & 2.76 \\
\hline 12 & Thuv & 6.4 & 6.8 & 22 & 17.1 & $3-4$ & 10 & 61 & 321 & 0.043 & 79 & 1.32 \\
\hline 13 & Naya & 6.8 & 4.1 & 21 & 16.4 & $4-5$ & 8 & 143 & 342 & 0.098 & 93 & 1.3 \\
\hline 14 & Chin & 6 & 6.3 & 22 & 18.3 & $5-6$ & 3 & 156 & 345 & 0.096 & 106 & 4.35 \\
\hline
\end{tabular}


The taxa like B con- Baetis conservatus, B ord- Baetis ordinatus, Ac ver- Acentrella vera, T flo- Thalerosphyrus flowersi, C ala- Choroterpes alagarensis, Ed lot- Edmundsula lotica, Ind bad-Indialis badia, Po gan-Potamanthellus ganges, Th gop- Thraulus gopalani, Te ins- Teloganodes insignis gets upheld by environmental attributes like $\mathrm{pH}$, altitude, hardness and alkalinity and negatively correlated with air temperature, water temperature, DO, BOD, TDS, conductivity and current speed. If riparian vegetation is high, there is an increase of $\mathrm{pH}$ in natural water (Wetzel, 2001). So the outcomes appears, the above taxa lean toward denser riparian environment for their source of living..Te fre- Tenuibaetis frequentus, Lb ger-Labiobaetis geminatus, Ce sim- Centroptella similis, Ce cey-Centroptella ceylonensis, A kum- Afronurus kumbakkaraiensis, C ala- Choroterpes alagarensis, I pur- Isca purpurea, $\mathrm{N}$ ind-Nathanella indica, No jo- Notophlebia jobi, Cae sp- Caenis sp gets enriched by the attributes like air temperature, water temperature, DO, BOD, TDS, conductivity and current speed and diminished by the factors $\mathrm{pH}$, altitude, hardness and alkalinity. They don't lean toward low temperature and low dissolved oxygen, so above reference taxa just incline toward cool condition and they are the markers of natural contamination since they are profoundly tolerant to the acidic and basic situations. B acc-Baetis acceptus, A ker-Afronurus sp., Ep pet- Epeorus petersi, $\mathrm{P}$ courPetersula courtallensis, Te den- Teloganodes dentata, Te kod- Teloganodes kodai and Eph nad- Ephemera nadinae shows no relation to any of the above 11 environmental variables.

The ordination diagram of CCA (Figure 10) displays the sites of Cardamom hills with species of Ephemeroptera and environmental variables. They display variation in species composition over the sites. From the results, sites C-3, C-4, C-8, C-10, C-13 and C-14 shows positive correlation with BOD, $\mathrm{pH}$, alkalinity and hardness and shows negative correlation with DO. Sites C-5, C-6, C-7, C-9, C-11 and C-12 shows positive correlation with TDS, conductivity and air temperature and negatively correlated with water temperature, current speed and altitude. Site 2 shows negative correlation with ecological attributes like TDS, conductivity and air temperature and shows positive correlation with water temperature, altitude and current speed.

Ce sim- Centroptella similis, T flo- Thalerosphyrus flowersi, $\mathrm{N}$ ind- Nathanella indica, P cour- Petersula courtallensis and Th gop-Thraulus gopalani were sensitive to low amount of $\mathrm{DO}$ and delicate to high discharge of BOD, $\mathrm{pH}$, alkalinity and hardness. It proves the above reference organisms are good indictaors of water quality because they are highly sensitive to acidic, alkaline environment. B acc-Baetis acceptus, $\mathrm{B}$ con- Baetis conservatus, B ord-Baetis ordinatus, Lb ger-
Labiobaetis geminatus, A ker- Afronurus sp., A kum- Afronurus kumbakkaraiensis, Ep pet- Epeorus petersi, $\mathrm{P}$ courPetersula courtallensis, Po gan- Potamanthellus ganges and Te den-Teloganodes dentata were sensitive to low BOD, $\mathrm{pH}$, alkalinity and hardness and sensitive to high DO. It shows that Baetis genera are tolerant to acidic and alkaline environment. Taxa such as Ce cey-Centroptella ceylonensis, Ac verAcentrella vera, Ed lot- Edmundsula lotica, I pur- Isca purpurea, No jo- Notophlebia jobi, Te kod- Teloganodes kodai and Te ins-Teloganodes insignis shows sensitivity to low levels of TDS, conductivity and air temperature and shows sensitivity to high levels of water temperature, current speed and altitude. Te fre- Tenuibaetis frequentus and Cae sp- Caenis $\mathrm{sp}$ shows sensitivity to high levels of TDS, conductivity and air temperature and shows less sensitivity to high levels of water temperature, whereas Ind bad- Indialis badia shows less sensitivity to altitude and current speed

Site C-1, which is not delicate to any of the eleven ecological factors, and Ephemera nadinae, which additionally shows no relationship or availability with any of the variable. The CCA results of both Palni and Cardamom hills substantiates that the distribution and community structure of Ephemera nadinae is mysterious and still needs further more investigation of overwhelming metals and other environmental properties. Baetis and Tenuibaetis both shows distinctive community structure pattern, though they both originates from a single ancestor. Gencer Turkmen and Ozkan (2011) and Gencer Turkmen and Nilgun Kazanci (2020) suggests that Baetis milani is $\beta$-mesosaprobic, our results also substantiates with that as Baetis species are sensitive to high DO and it prefers $\beta$-mesosaprobic habitat. According Caenis sp. in both Palni and Cardamom hills prefers different habitats and it proves that more Caenis species complex were present in Palni and Cardamom hills. The outcome likewise demonstrates Indialis badia diversity and distribution were more in high altitudinal area. From the results, it is apparent that Centroptella similis prefer oligosaprobic environment.

It was noticed that locales Poomparai, Dhobikana, Kounchi of Palni hills and Kurangani up and down of Cardamom hills are plotted away from all the variables and the only reason that can be suggested is human impedance (i.e. Anthropogenic impacts). 


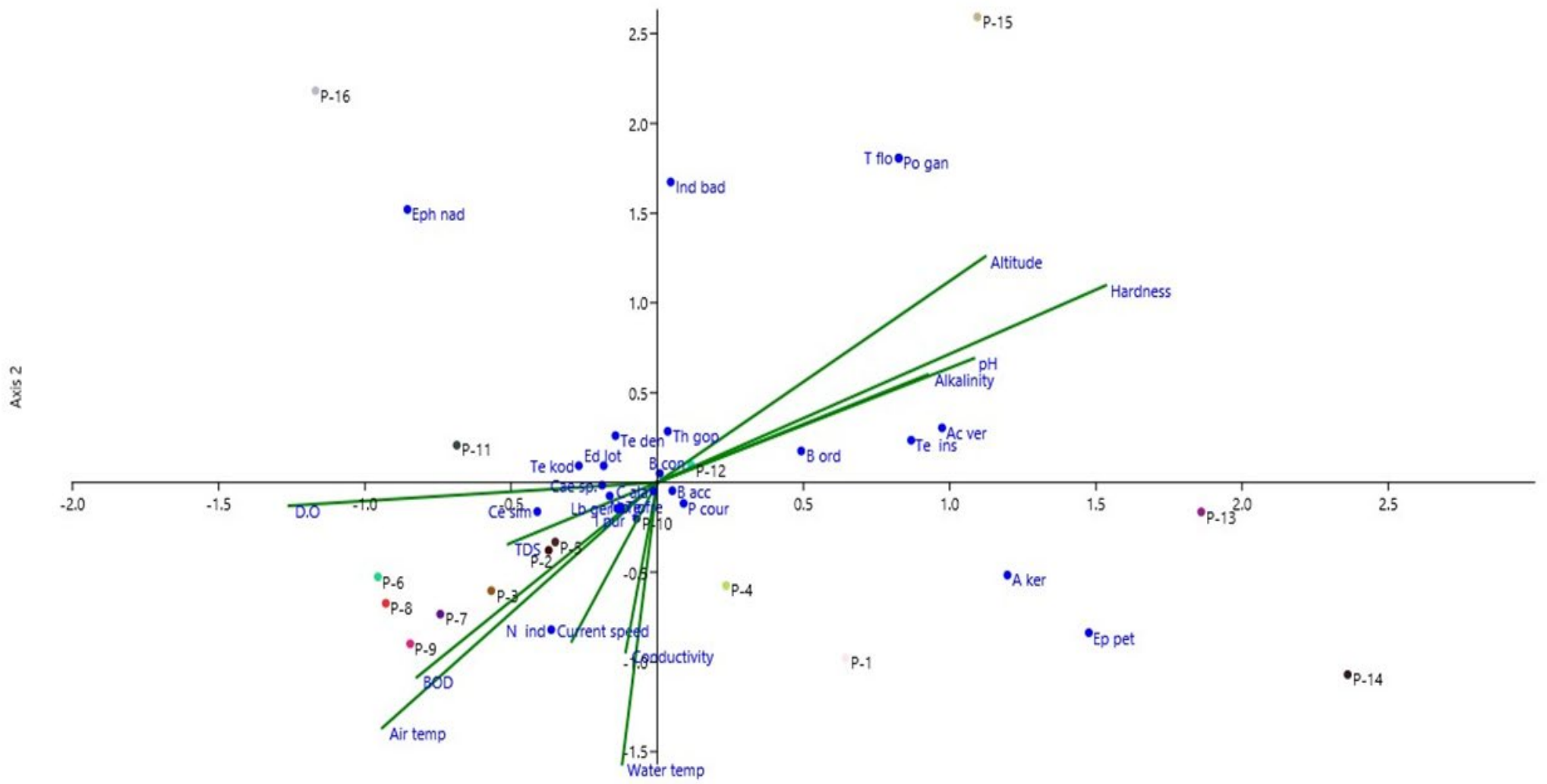

(B acc- Baetis acceptus, B con- Baetis conservatus, Te fre- Tenuibaetis frequentus, B ord- Baetis ordinatus, Lb ger-Labiobaetis geminatus, Ce sim- Centroptella similis, Ce cey- Centroptella ceylonensis, Ac ver-Acentrella vera, A ker-Afronurus sp, A kum-Afronurus kumbakkaraiensis, Ep pet- Epeorus petersi, $\mathrm{T}$ flo- Thalerosphyrus flowersi, $\mathrm{C}$ ala- Choroterpes alagarensis, Ed lot- Edmundsula lotica, Ind badIndialis badia, I pur- Isca purpurea, $\mathrm{N}$ ind- Nathanella indica, No jo- Notophlebia jobi, P cour- Petersula courtallensis, Po gan- Potamanthellus ganges, Th gop- Thraulus gopalani, Te den- Teloganodes dentata, Te kod- Teloganodes kodai, Te ins- Teloganodes insignis, Eph nad- Ephemera nadinae, Cae sp- Caenis sp.)

Figure 9. Canonical Correlation Analysis of Palni hills 


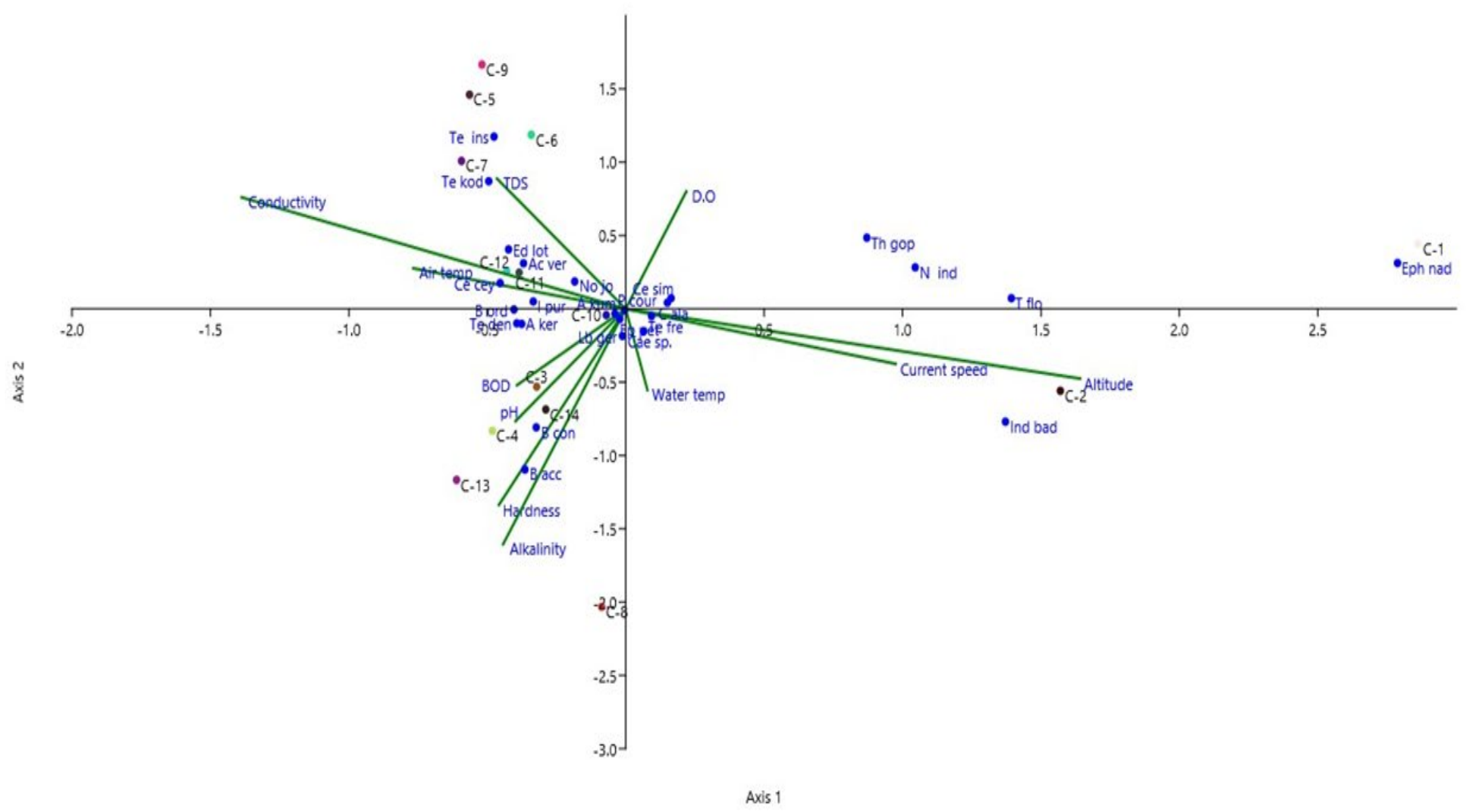

(B acc- Baetis acceptus, B con- Baetis conservatus, Te fre- Tenuibaetis frequentus, B ord- Baetis ordinatus, Lb ger- Labiobaetis geminatus, Ce sim- Centroptella similis, Ce cey-Centroptella ceylonensis, Ac ver-Acentrella vera, A ker-Afronurus sp., A kum- Afronurus kumbakkaraiensis, Ep pet- Epeorus petersi, T flo- Thalerosphyrus flowersi, $\mathrm{C}$ ala- Choroterpes alagarensis, Ed lot- Edmundsula lotica, Ind badIndialis badia, I pur- Isca purpurea, $\mathrm{N}$ ind- Nathanella indica, No jo- Notophlebia jobi, P cour- Petersula courtallensis, Po gan- Potamanthellus ganges, Th gop- Thraulus gopalani, Te den- Teloganodes dentata, Te kod- Teloganodes kodai, Te ins- Teloganodes insignis, Eph nad- Ephemera nadinae, Cae sp- Caenis sp.)

Figure 10. Canonical Correlation Analysis of cardamom hills

\section{Conclusions}

Based on PCA results, it tends to be reasoned that the sites in Palni hills, which are plotted far apart like Dhobikana, Fern hill and Poomparai, are not supported by the physico-chemical parameters like the other sites in Palni hills. This is absolutely a direct result of anthropogenic activity, because Fern hill and Poomparai are excursion spots where human obstruction is more in these streams. Whereas Dhobikana is a place where dhobis are involved in washing clothes so detergent pollution is more there. In cardamom, hills Santhamparai near bridge and Nayamakkadu are left far apart indicating they are not supported by physicochemical parameters, mainly due to pollution. However, Ephemeroptera were sensitive to water quality changes specially to $\mathrm{DO}, \mathrm{pH}$, conductivity and hardness their number is less in these stations compare with other stations. From the CCA results, it is found that Baetis species lean towards $\beta$-mesosaprobic habitat and Indialis badia favors high altitudinal area. Sites like Poomparai, Dhobikana, Kounchi of Palni hills and Kurangani up and down of Cardamom hills are plotted away from all the environmental variables. 
In this work, it is discovered that not all physicochemical parameters are emphatically or adversely corresponded. But it is understood that $\mathrm{pH}$, dissolved oxygen, $\mathrm{BOD}$, hardness and alkalinity were the crucial factors. This agrees with numerous investigations that have been done previously (Steinman et al., 2003). Dissolved oxygen is the key to the abundance of Ephemeroptera as oxygen is the significant component to all living creature to remain alive and slight changes on the $\mathrm{pH}$ likewise change the presence of Ephemeroptera.

\section{Compliance with Ethical Standard}

Conflict of interests: The authors declare that for this article they have no actual, potential or perceived conflict of interests.

Ethics committee approval: This study was conducted in accordance with ethics committee procedures of animal experiments.

Funding disclosure: -

Acknowledgments: -

Disclosure: -

\section{References}

APHA (American Public Health Association) (2005). Standard methods for the examination of water and wastewater, 21st Edition, Washington D.C. ISBN: 9780875530475

BarberJames, H.M., Gattolliat, J.L, Sartori, M., Hubbard, M.D. (2008). Global diversity of mayflies (Ephemeroptera: Insecta) in freshwater. Hydrobiologia, 595, 339-350. https://dx.doi.org/10.1007/s10750-007-9028-y

Benstead, J.P., Pringle, C.M. (2004). Deforestation alters there source base and biomass of endemic stream insects in eastern Madagascar. Freshwater Biology, 49, 490-501. https://doi.org/10.1111/j.1365-2427.2004.01203.x

Burton, T.M., Sivaramakrishnan, K.G. (1993). Composition of the insect community in the streams of the silent valley National Park in South India. Journal of Tropical ecology, 34, 1-16.

Campbell, G., Wildberger, S. (2001). The monitor's handbook. A Reference Guide for Natural Water Monitoring, LaMotte Company, Chestertown, Maryland, USA, 6 p.

Duran, M., Akyildiz, G.K. (2011). Evaluating benthic macroinvertebrate fauna and water quality of Suleymanli Lake (Buldan-Denizli) in Turkey. Acta Zoologica Bulgarica, 63(2), 169-178.
Fakayode, S.O. (2005). Impact of industrial effluents on water quality of the receiving Alaro River in Ibadan, Nigeria, African Journal of Environmental Assessment and Management, 10, 1-13.

Goodfellow, W.L., Ausley, L.W., Burton, D.T., Denton, D.L., Dorn, P.B., Grothe, D.R., Heber, M.A., Norberg King, T.J., Rodgers, J.H. Jr. (2000). Major ion toxicity in effluents: a review with permitting recommendations. Environmental Toxicology and Chemistry, 19, 175-182.

https://doi.org/10.1002/etc.5620190121

Hammer, O., Harper, D.A.T., Ryan, P.D. (2001). PAST (Paleontological Statistics software package for education and data analysis). Palaeontologia Electronica, 4(1), 9.

Kazanci, N., Türkmen, G., Ekingen, P., Basoren, O. (2017). Evaluation of Plecoptera (Insecta) community composition using multivariate technics in a biodiversity hotspot. International Journal of Environmental Science and Technology, 14, 1307-1316.

https://doi.org/10.1007/s13762-017-1245-y

Lenat, D.R., Barbour, M.T. (1994). Using benthic macroinvertebrate community structure for rapid, cost-effective, water quality monitoring: rapid bioassessment.Biological monitoring of aquatic systems, Lewis Publishers, Boca Raton, Florida, pp. 187-215.

McKee, D., Atkinson, D. (2000). The influence of climate change scenarios on populations of the mayfly Cloeon dipterum. Hydrobiologia, 441, 55-62.

https://doi.org/10.1023/A:1017595223819

Myers, N., Mittermeier, R.A., Mittermeier, C.G., Da Fonseca, G.A., Kent, J. (2000). Biodiversity hotspots for conservation priorities. Nature, 403(6772), 853.

https://doi.org/10.1038/35002501

Payne, A.L. (1986). The ecology of tropical lakes and rivers. Londres: John Wiley \& Sons. pp. 327-328. ISBN: 0471-90524-0

Pond, G.J., Passmore, M.E., Borsuk, F.A., Reynolds, L., Rose, C.J. (2008). Downstream effects of mountaintop coal mining: Comparing biological conditions using family- and genus- level macroinvertebrate bioassessment tools. Journal of the North American Benthological Society, 27, 717-737. https://doi.org/10.1899/08-015.1 
Rosenberg, D.M., Resh, V.H. (1993). Freshwater biomonitoring and benthic macroinvertebrates. Chapman \& Hall, New York. pp. 1-9. ISBN: 0412022516

SETAC (Society of Toxicology and Chemistry) (2004). Technical issue paper: Whole effluent toxicity testing: ion imbalance. Pensacola, FL, USA, 4 p.

Srinivasan, P., Sivaruban, T., Isack, R., Barathy, S. (2019). Bio-monitoring and detection of water quality using Ephemeroptera, Plecoptera and Trichoptera (EPT) complex in Karanthamalai Stream of Eastern Ghats. Indian Journal of Ecology, 46(4), 818-822.

https://doi.org/10.1672/0277-

5212(2003)023[0877:IOCGAP]2.0.CO;2

Steinman, A.D., Conklin, J., Bohlen, P.J., Uzarski, D.G. (2003). Influence of cattle grazing and pasture land use on macroinvertebrate communities in freshwater wetlands. Wetlands, 23, 877-889.
Türkmen, G., Kazanci N. (2020). Community Structure of Mayflies (Insecta: Ephemeroptera) in a Biodiversity Hotspot as Revealed by Multivariate Analyses. Acta Zoologica Bulgarica, 72(1), 67-81.

Türkmen, G., Ozkan, N. (2011). Larval Ephemeroptera records from Marmara Island and Kapıdağ Peninsula (NorthWestern Turkey) with new record of Baetis milani Godunko, Prokopov \& Soldan 2004. Review of Hydrobiology, 4(2), 99113.

Wetzel, R.G. (2001). Limnology - Lake and river ecosystem, $3^{\text {rd }}$ edition, USA.

https://doi.org/10.1007/BF00731036

Zwick, P. (1992). Stream habitat fragmentation - a threat to biodiversity. Biodiversity Conservation, 1, 80-97. 